\title{
UNIVERSITY OF GEORGIA RADIOCARBON DATES I
}

\author{
JOHN E. NOAKES and BETTY LEE BRANDAU
}

University of Georgia, Geology Department, Athens, Georgia

The Geochronology Laboratory of the University of Georgia was established in the fall of 1969. The laboratory is housed in the basement of the Geology Building and is under the direction of the General Research Department. Radiocarbon dating facilities are the first to be developed in the laboratory. Other methods will be employed to date a wide spectrum of samples over extensive age ranges. Facilities of the laboratory are also available to colleges, universities, and institutions for teaching and research.

Carbon-containing samples are converted to benzene and $\mathrm{C}^{14}$ activity is determined by liquid-scintillation spectroscopy. Samples are first converted to lithium carbide and then to acetylene gas as described by Barker (1953). The acetylene is trimerized to benzene with a vanadium alumina catalyst developed at ORINS. Chemical yields for benzene approach $90 \%$ with no evidence of chemical impurities in the benzene to cause quenching or of carbon-isotope fractionation occurring in the chemistry. Benzene chemistry, catalyst, benzene purity, and $\mathrm{C}^{13} /{ }^{12}$ isotope-fractionation studies are reported by Noakes et al. (1965).

The two liquid scintillation spectrometers used are modified Model 220 Picker Nuclear counters. Counting efficiency is approximately $70 \%$ at a voltage of 2300 with a discriminator window set above the maximum energy for tritium and radiocarbon. Background count rate is approximately $4 \mathrm{cpm}$ with a $5 \mathrm{cc}$ benzene sample. Shielding consists of 3 inches of lead with coincidence and anti-coincidence systems.

The modern reference standard is $95 \%$ of the activity of the NBS oxalic-acid standard $\left(9.55 \mathrm{c} / \mathrm{m} / \mathrm{g}\right.$ carbon). Ages are calculated on a $\mathrm{C}^{14}$ half-life of 5570 as suggested by Godwin (1962). The statistics quoted are one standard deviation $\left(1_{\sigma}\right)$ of the uncertainty involved in counting background, standard, and sample.

\section{ACKNOWLEDGMENTS}

Brian Logan, Geology Department, University of Western Australia, contributed many samples and assisted in their evaluation. John Hoyt, Sapelo Island Marine Laboratory, University of Georgia, made available facilities at his laboratory, contributed samples, and helped in their evaluation. W. C. Ward, Geology Department, Rice University, collected samples.

\section{GEOLOGIC SAMPLES}

\section{A. Eastern Florida and Georgia Coast, U.S.A.}

The following $\mathrm{C}^{14}$ dates are from shell material collected to determine the age of Pleistocene coastal deposits. 


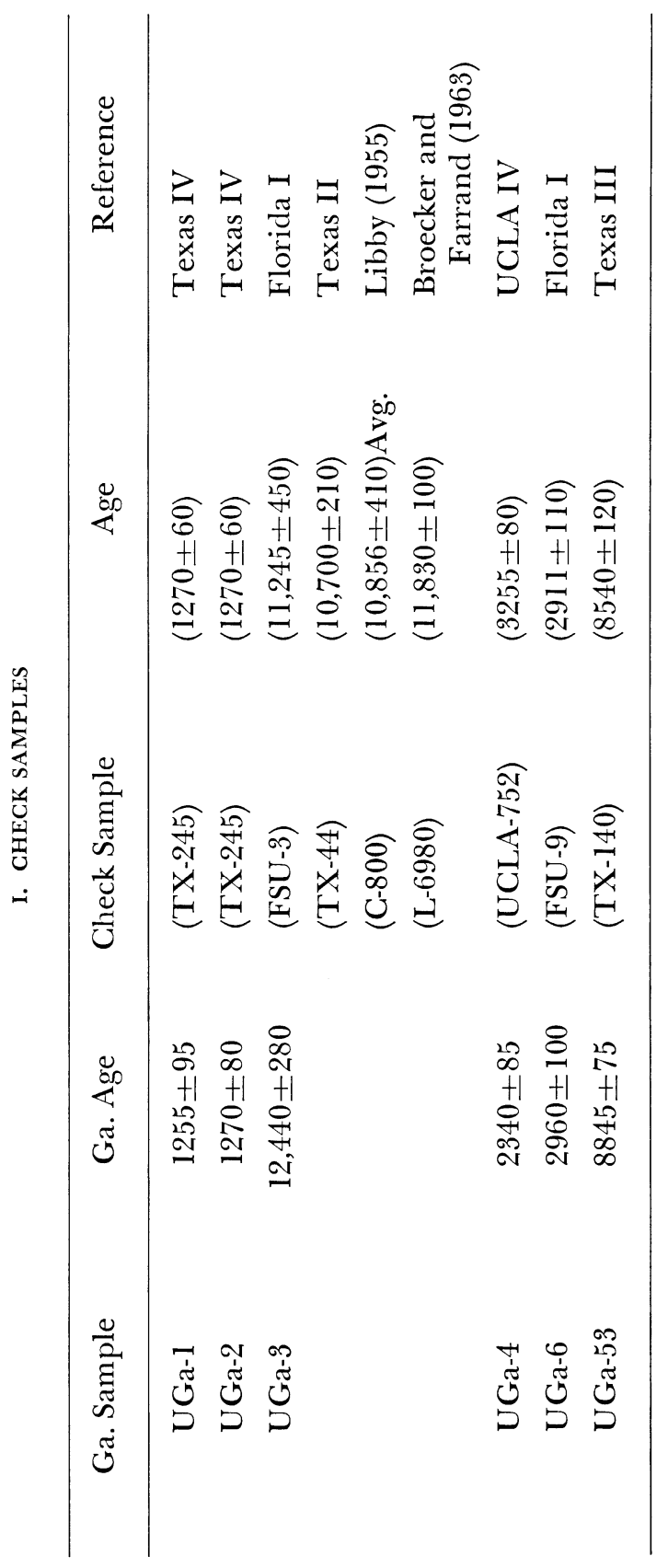


UGa-7. Marineland, Florida

Shells from coquina outcrop on beach S of Marineland $\left(29^{\circ} 39^{\prime} 44^{\prime \prime}\right.$ N Lat, $81^{\circ} 12^{\prime} 35^{\prime \prime}$ W Long) about mean sea level (MSL). Coll. and subm. 1968 by John Hoyt. Comment: thought to be Silver Bluff but date shows a more recent deposition.

\section{UGa-8. Merritt Island, Florida}

$27,760 \pm 1200$

Broken shells from coquina $1.33 \mathrm{~m}$ above MSL $\left(28^{\circ} 40^{\prime} 55^{\prime \prime} \mathrm{N}\right.$ Lat, $80^{\circ} 43^{\prime} 8^{\prime \prime} \mathrm{W}$ Long). Coll. and subm. 1968 by John Hoyt. Comment: Silver Bluff.

UGa-9. Bon Terra, Florida $>40,000$

Small broken shells, cemented together with quartz sand, from coquina; same location as UGa-11, $0.33 \mathrm{~m}$ above MSL. Coll. and subm. 1968 by John Hoyt.

\section{UGa-10. Bon Terra, Florida}

$29,780 \pm 1340$

Shells of Mulina, Tellina, Donax, Arca, some broken from coquina; same location as UGa-11, $1.0 \mathrm{~m}$ above MSL. Coll. and subm. 1968 by John Hoyt.

\section{UGa-11. Bon Terra, Florida}

$27,960 \pm 1200$

Shells of Mulina, Tellina, Donax, Arca, some broken. From coquina, ca. $0.6 \mathrm{~m}$ below surface of bluff ca. $3.6 \mathrm{~m}$ above MSL $\left(29^{\circ} 33^{\prime} 50^{\prime \prime} \mathrm{N}\right.$ Lat, $81^{\circ} 10^{\prime} 58^{\prime \prime} \mathrm{W}$ Long). Coll. and subm. 1968 by John Hoyt. Comment: UGa-11, 10, and 9 show increasing age with depth in the bluff. UGa-11 and 10 are Silver Bluff in age and UGa-9 is considerably older.

\section{UGa-12. Daytona Beach, Florida}

$24,330 \pm 560$

Small broken shells from coquina, ca. $7.6 \mathrm{~m}$ above MSL $\left(29^{\circ} 13^{\prime} 0^{\prime \prime}\right.$ N Lat, $81^{\circ} 4^{\prime} 53^{\prime \prime}$ W Long). Coll. and subm. 1968 by John Hoyt. Comment: was thought to be Pamlico but age shows this to be a Silver Bluff deposit.

\section{UGa-15. Flagler Beach, Florida}

Small broken shells from coquina, from quarry $4.3 \mathrm{~km} \mathrm{~W}$ of Flagler Beach (29 $28^{\prime} 36^{\prime \prime} \mathrm{N}$ Lat, $81^{\circ} 12^{\prime} 54^{\prime \prime} \mathrm{W}$ Long) ca. $7.3 \mathrm{~m}$ above MSL. Coll. and subm. by John Hoyt. Silver Bluff deposit.

\section{UGa-17. Rieds Bluff, Florida}

Unbroken oyster shells taken from thick gray clay in S bank of St. Mary's R. ( $30^{\circ} 43^{\prime} 10^{\prime \prime} \mathrm{N}$ Lat, $81^{\circ} 35^{\prime} 40^{\prime \prime} \mathrm{W}$ Long) ca. $3.7 \mathrm{~m}$ above MSL. Coll. and subm. 1968 by John Hoyt. Comment: probably Pamlico. 
Whole oyster shells from bank of Duplin R. (31 $27^{\prime} 15^{\prime \prime} \mathrm{N}$ Lat, $81^{\circ}$ $17^{\prime} 10^{\prime \prime} \mathrm{W}$ Long) from blue-gray clay, 0.3 to $0.6 \mathrm{~m}$ below MSL. Coll. and subm. by John Hoyt. Comment: Silver Bluff.

UGa-19. Pamlico Lagoon, Georgia

Dolostone with some clay from a chalky dolostone bed 25 to $38 \mathrm{~mm}$ thick, dense, cherty looking, calcareous and chalky, white to pale yellow, from $8 \mathrm{~km} \mathrm{~W}$ of Brunswick near intersection of Massey Causeway and Buck Swamp-Sandhill R., Glynn Co. (31 $11^{\prime} 20^{\prime \prime}$ N Lat, $81^{\circ} 42^{\prime} 30^{\prime \prime} \mathrm{W}$ Long). Sample from 38.3 to $39.5 \mathrm{~cm}$ below surface, alt. $4.5 \mathrm{~m}$. Overlying material is clay, (oyster shell and shell hash mixture). Coll. and subm. 1969 by T. F. Logan, Jr., Univ. of Georgia. Comment: age indicates Pamlico.

General Comment: samples were from deposits that, based on regional maps and alt., were believed Pamlico or Silver Bluff in age. This series dates Silver Bluff shoreline more precisely. "Silver Bluff" applies to 25,000 to 36,000 yr ago; "Pamlico" to an earlier beach, probably Sangamon or last traditional interglacial.

\section{B. Northeast Coast of Yucatan Peninsula, Mexico}

The Caribbean coast of the Yucatan Peninsula, Mexico, is the site of a variety of shallow-water and sub-aerial carbonate sediments. In 1967, a group from the Dept. of Geol., Rice Univ., began a study of carbonate sedimentation and diagenesis along the NE part of this coast. Dates were measured to establish ages, and rates of diagenesis, of Holocene and Pleistocene calcareous eolianites.

\section{UGa-18. Isla Cancun}

$13,590 \pm 200$

Whole-rock sample of tan to reddish eolianite, fairly well lithified (21 ${ }^{\circ} 8^{\prime} 20^{\prime \prime} \mathrm{N}$ Lat, 86 $46^{\circ} \mathrm{W}$ Long). Coll. and subm. 1967 by W. C. Ward. Comment: geomorphology suggests this eolianite, though well lithified, is Holocene. Age probably in error because the whole rock has a high content of reworked limestone fragments.

\section{UGa-20. Isla Cancun}

A.D. 1200

$750 \pm 80$

Oolitic calcarenite from Caribbean Sea $69 \mathrm{~m}$ off N end of Isla Cancun $\left(21^{\circ} 8^{\prime} \mathrm{N}\right.$ Lat, $86^{\circ} 46^{\prime} \mathrm{W}$ Long). Sample from beneath $4.5 \mathrm{~m}$ water and is the fine fraction passing through \#60 sieve. Coll. and subm. 1968 by W. G. Ward. Comment: controversy whether the calcareous sand is receiving oolite coatings or whether coated grains reworked from oolitic island and coastal rock. Separated coarser fraction eliminated bulk of the non-coated bioclasts. Date indicates sample is modern.

UGa-22. Isla Cancun

$1030 \pm 80$

Shell (Strombus) from sea cliff in Caribbean shore off island at base 
of eolianite ( $21^{\circ} 8^{\prime} \mathrm{N} \mathrm{Lat}, 86^{\circ} 46^{\prime} \mathrm{W}$ Long). Coll. and subm. 1967 by W. C. Ward. Comment (W.C.W.): Strombus is one of few fossils found in area; was taken from a calcarenite deposit which underlies $4.5 \mathrm{~m}$ of eolianite equivalent to UGa-18. Early date indicates an intrusion.

UGa-21.

$$
1900 \pm 90
$$

Sample of caliche crust from W edge of N Saline Lake $\left(21^{\circ} 14^{\prime} \mathrm{N}\right.$ Lat, $86^{\circ} 45^{\prime} \mathrm{W}$ Long) developed on the Pleistocene eolianite country rock of the island. Coll. and subm. 1968 by W. C. Ward.

\section{Western Australia}

\section{Shark Bay series}

Shark Bay is a lagoonal sea lying between $24^{\circ} 30^{\prime} \mathrm{S}$ and $26^{\circ} 45^{\prime} \mathrm{S}$ Lat on W coast of Australia. Since 1964 a marine-research group from Dept. of Geol., Univ. of Western Australia has conducted a program on sedimentation and diagenesis of carbonate sediments in Shark Bay. The following $\mathrm{C}^{14}$ dates are mainly on shell materials obtained from emergent Quaternary sediments in the area.

\section{UGa-27. Shark Bay, Western Australia}

$5370 \pm 70$

Costacallistra impar from location similar to UGa-30 $1 \mathrm{~m}$ below surface (26 $26^{\circ} \mathrm{S}$ Lat, $113^{\circ} 30^{\prime} \mathrm{E}$ Long). Coll. by B. W. Logan, Univ. of Western Australia.

\section{UGa-28. Shark Bay, Western Australia}

$4040 \pm 70$

Terebrailia sulcatus specimens from shallow excavation, supratidal flat, Depuch Loop, Shark Bay (26³ $36^{\prime}$ S Lat, $113^{\circ} 33^{\prime} 34^{\prime \prime}$ E Long). Coll. by B. W. Logan.

\section{UGa-29. Shark Bay, Western Australia}

Placamen sp. from shallow excavation, supratidal flat, Dupuch Loop, Shark Bay (26 $37^{\prime} 15^{\prime \prime}$ S Lat, $113^{\circ} 35^{\prime} 15^{\prime \prime}$ E Long). Coll. by B. W. Logan.

\section{UGa-30. Shark Bay, Western Australia}

$$
5140 \pm 70
$$

Costacallistra impar from $1 \mathrm{~m}$ below surface of Inlet, Shark Bay (26 $28^{\prime} 36^{\prime \prime} \mathrm{S}$ Lat, $113^{\circ} 30^{\prime} \mathrm{E}$ Long). Coll. by B. W. Logan.

\section{UGa-31. Shark Bay, Western Australia}

$3630 \pm 70$

Cryptogramma sp. from same location as UGa-30. Coll. by B. W. Logan. 
UGa-32. Shark Bay, Western Australia

Costacallistra impar from a claypan, $2.4 \mathrm{~km} \mathrm{~W}$ of Biddy Giddy Out-

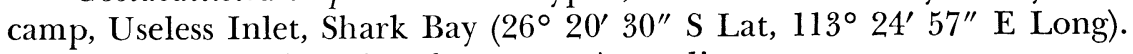
Coll. by F. J. Read, Univ. of Western Australia.

\section{UGa-34. Shark Bay, Western Australia}

$36,800 \pm 1300$

Coral (Favites sp.) from $3 \mathrm{~m}$ emergent reef, Tetradon Loop, Dirk Hartog I. Shark Bay (25 56 $30^{\prime \prime} \mathrm{S}$ Lat, $113^{\circ} 9^{\prime} \mathrm{E}$ Long). Coll. by F. J. Read.

\section{UGa-35. Shark Bay, Western Australia}

$47,200 \pm 5200$

Coral (Montastrea sp.) from same location as UGa-34. Coll. by F. J. Read.

\section{UGa-36. Shark Bay, Western Australia}

$39,900 \pm 1800$ 37,950 в.c.

Coral (Favia sp.) from supratidal flats $\mathrm{N}$ of Hutchinson I. embayment, Shark Bay $\left(26^{\circ} 4^{\prime} \mathrm{S}\right.$ Lat, $114^{\circ} 12^{\prime} 40^{\prime \prime}$ E Long). Coll. by B. W. Logan.

\section{UGa-37. Shark Bay, Western Australia}

$42,500 \pm 2400$

Coral (Simplastrea) from same location as UGa-36. Coll. by B. W. Logan.

$4180 \pm 70$

UGa-38. Shark Bay, Western Australia

2230 B.C.

Fragum unedo from same location as UGa-32. Coll. by F. J. Read.

\section{UGa-40. Shark Bay, Western Australia}

$35,900 \pm 2100$

Mollusk shells from the upper supratidal zone, Gladstone Embayment, Shark Bay (24 $54^{\prime} 30^{\prime \prime} \mathrm{S}$ Lat, $114^{\circ} 13^{\prime} 30^{\prime \prime}$ E Long). From base of gypsum dune, mainly of Pitarina citrina and Circe sugillata. Coll. and id. by G. R. Davies, Univ. of Western Australia.

\section{UGa-42. Shark Bay, Western Australia}

$$
4500 \pm 70
$$

2550 B.c.

Mixed mollusk fauna from cores taken in the Gladstone Embayment, Shark Bay $\left(25^{\circ} 54^{\prime} 30^{\prime \prime} \mathrm{S}\right.$ Lat, $114^{\circ} 13^{\prime} 30^{\prime \prime}$ E Long). From 2 cores, same horizon, from over $15 \mathrm{~cm}$ sample interval at depth $-1.2 \mathrm{~m}$. Contains Circe suggillata, Chama sp., Fragum unedo, Circe plicatina, Pitarina citrina, and a few cerithiids. Coll. and id. by G. R. Davies.

UGa-43. Shark Bay, Western Australia $>40,000$

Coral (Porites sp.) from outcrop on intertidal flat, Gladstone Em-

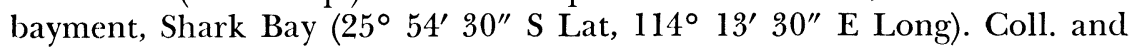
id. by G. R. Davies. 
UGa-39. Hamelin Pool, Western Australia

Coquina consisting of pelecypod (Fragum hamelini) from weakly cemented recent beach-ridge sediments, Hamelin Pool, Western Australia (26 $23^{\prime} 30^{\prime \prime} \mathrm{S}$ Lat, $114^{\circ} 10^{\prime} \mathrm{E}$ Long). Coll. and id. by B. W. Logan.

\section{UGa-41. Hamelin Pool, Western Australia}

Ooids from SE margin of Anchorage Bank, Hamelin Pool, Western Australia (26 $8^{\prime} 30^{\prime \prime} \mathrm{S}$ Lat, $113^{\circ} 56^{\prime} 35^{\prime \prime} \mathrm{E}$ Long). Depth $1.5 \mathrm{~m}$. Coll. by B. W. Logan.

General Comment: dates from Shark Bay and Hamelin Pool have permitted a view of Quaternary sea levels in this area. The carbon dates establish a higher sea level of 1.5 to $2.5 \mathrm{~m}$ during the last 5 to $6000 \mathrm{yr}$. The older dates on the emergent reefs made a mid-Wisconsin high sea level seem real.

\section{REFERENCFS}

Barker, Harold, 1953, Radiocarbon dating: Large scale preparation of acetylene from organic material: Nature, v. 172, p. 631-632.

Berger, Rainer, Fergusson, G. J., and Libby, W. F., 1965, UCLA radiocarbon dates IV: Radiocarbon, v. 7, p. 386-371.

Brocker, W. S. and Farrand, W. R., 1963, Radiocarbon age of the Two Creeks Forest Bed, Wisconsin: Geol. Soc. America Bull., v. 74, p. 795-802.

Godwin, Harry, 1962, Half-life of radiocarbon: Nature, v. 195, p. 984.

Libby, W. F., 1955, Radiocarbon dating, 2nd ed.: Chicago, Univ. Chicago Press, ix, p. 126.

Logan, B. W., 1957, Environments, foraminiferal facies and sediments of Shark Bay, Western Australia: Ph.D. dissert., Dept. Geol., Univ. of W. Australia, 287 p.

Noakes, J. E., Kim, S. M., Stipp, J. J., and Akers, L. K., 1965, Chemical and counting advances in liquid scintillation radiocarbon dating: Sixth internatl. conf. radiocarbon and tritium dating Proc., Pullman, Washington, p. 68-92.

Pearson, F. J., Jr., Davis, E. M., and Tamers, M. A., 1966, Univ. of Texas radiocarbon dates IV: Radiocarbon, v. 8, p. 453-466.

Pearson, F. J., Jr., Davis, E. M., Tamers, M. A., and Johnstone, R. W., 1965, University of Texas radiocarbon dates III: Radiocarbon, v. 7, p. 296-314.

Stipp, J. J., Knauer, G. A., and Goodell, H. G., 1966, Florida State University radiocarbon dates I: Radiocarbon, v. 8, p. 46-53.

Tamers, M. A., Pearson, F. J., Jr., and Davis, E. M., 1964, University of Texas radiocarbon dates II: Radiocarbon, v. 6, p. 138-159. 